\title{
African Immigrant Entrepreneurs in South Africa: Exploring Their Economic Contributions
}

\author{
Bernard Lama Ngota, Sookdhev Rajkaran, Eric Ernest Mang'unyi
}

\section{A B S T R A C T}

Objective: The objective of this article is to determine the economic opportunities created by African immigrant entrepreneurs in South Africa. Furthermore, it is to investigate the impact that Afrophobia has on economic opportunities created by African immigrant entrepreneurs in South Africa.

Research Design \& Methods: The text utilizes a mixed-methods approach that incorporates both self-administered questionnaire and qualitative in-depth interviews. Through a random sampling approach and snowballing technique, this study combines data from questionnaires of 153 participants and in-depth interviews with 12 respondents.

Findings: The findings confirm that immigrant SMEs fill economic gaps by contributing to innovation and technology developments. Such commercial migrants pay taxes, thus adding to the economy of the country. Challenges faced by African immigrant entrepreneurs are not few but centre on Afrophobic and xenophobic attacks which negatively impact business operations and economic growth.

Implications \& Recommendations: Sound measures by the government regarding immigration could minimize existing tensions, stimulate local skills development, technology development and transfer, new business opportunities, and improve inclusion into the globalised economy.

Contribution \& Value Added: This study is unique in that it contributes to our knowledge and literature on immigrant entrepreneurship while particularly providing insights into African immigrants' contributions to a national economy.

\begin{tabular}{lll}
\hline Article type: & research article \\
Keywords: & $\begin{array}{l}\text { African immigrant entrepreneurs; entrepreneurial challenges; Small } \\
\text { and Medium Enterprises; South Africa }\end{array}$ \\
JEL codes: & J15, L26, M10 \\
\hline \multicolumn{2}{c}{ Received: 28 May $2019 \quad$ Revised: 12 October $2019 \quad$ Accepted: 9 November 2019}
\end{tabular}




\section{INTRODUCTION}

The role that immigrants play in the economic development of a country is well acknowledged (Ekwulugo, 2006; DeLancey, 2014; Fatoki, 2014; Marchand \& Siegel, 2014; Khosa \& Kalitanyi, 2015). Immigrants are widely perceived to be highly entrepreneurial; contributing to economic growth and innovation (Hohn, 2012; Marchand \& Siegel, 2014), with self-employment often viewed as a means of enhancing labour market integration and success (Beaujot, Maxim, \& Zhao, 1994; Bogan \& Darity, 2008; Douglas \& Shepherd, 2002; Portes \& Zhou, 1996). Through entrepreneurship, immigrants reduce unemployment by investing the necessary resources into numerous sectors with potential growth (Thomas \& Inkpen, 2013). As such, immigrant entrepreneurship is an important driver for the socio-economic development of host and home countries (Ojo, Nwankwo, \& Gbadamosi, 2013; Turkina \& Thai, 2013).

Scholars justify the impact of migrants to host economies in various forms (e.g. Anderson \& Platzer, 2006; Borjas, 1990; Friedberg \& Hunt, 1995; Hart \& Acs, 2011; Ngota, 2017; Ojo et al., 2013). For example, in the United States of America, it has been established that immigrant entrepreneurs significantly contribute to the technology and engineering sectors of the economy (Hunt \& Gauthier-Loiselle, 2010; Hart \& Acs, 2011; Fairlie \& Lofstrom, 2014). Scholars acknowledges that immigrants have striking entrepreneurial propensity and their businesses significantly contribute to job creation, innovation, transfer of skills to locals (DeLancey, 2014; Dele-ljagbulu \& Chirau, n.d.; Kalitanyi \& Visser, 2010; Mabadu, 2014; Ngota, Rajkaran, Balkaran, \& Mang'unyi, 2017; Ojong, 2006; Saxenian, 2002; Vertovec, 2002) and gross domestic product (GDP); (Liebig \& Mo, 2013; Brewer \& Gibson, 2014). Therefore, through their entrepreneurial activities, immigrant entrepreneurs create wealth that reduces locals' dependence on the government for providing jobs (Mabadu, 2014), as they predictably become the leading employers in South Africa's economy (Kongolo, 2010).

Although entrepreneurship provides immigrants' societal self-respect in their host country, African immigrant SME owners face many obstacles (Asoba \& Tengeh, 2016). For instance, according to Mabadu (2014), immigrants face major difficulties with regard to settlement and integration into the job market, which is as a result of discrimination and 'limited' skills. For example, in South Africa, perceptions, particularly about black foreigners regarded as 'dangerous' and 'undesirable' - often termed by locals as 'kwerekwere' (Maharaj, 2002) - gradually increased the 'Afrophobia' phenomenon in recent years (Crush, Ramachandran, \& Pendleton, 2013). This 'phobia' has adverse consequences on job creation and trading activities (Hunter \& Skinner, 2003). Further issues that hinder the flourishing of African immigrant businesses are gathering resources to start a business (Fatoki \& Patswawairi, 2012; Urban \& Naidoo, 2012; Mabadu, 2014; Khosa \& Kalitanyi, 2015), access to reasonable business premises (Khosa \& Kalitanyi, 2014), stringent government regulations (Asoba \& Tengeh, 2016), and inadequate managerial and financial management competencies (Kim, Park, \& Wier, 2012; Smith \& Watkins, 2012).

It is evident that SMEs - specifically those owned by immigrants - are major contributors to every developed economy (Asoba \& Tengeh, 2016). Hence, the immigrant SMEs cannot be an exception, even though their contributions continues to be underrepresented in the academic literature. Studies conducted in Africa mainly focus on factors that 
contribute to or impede immigrant entrepreneurial development (Mubangizi \& Mubangizi, 2005; Radipere, 2012; Tengeh, Ballard, \& Slabbert, 2012; Fatoki, 2014; Khosa \& Kalitanyi, 2014; Asoba \& Tengeh, 2016). However, there increasingly appear concerns about immigrants' contributions to the South African economy (Ojong, 2006). Studies on the impact of African immigrants on local economies in South Africa are limited and rare. Many of the studies on immigrant entrepreneurship focus on USA-based, Asian, and European economies (DeLancey, 2014; Fairlie \& Lofstrom, 2014; Marchand \& Siegel, 2014). This is theoretically and practically challenging, as data collected from such research cannot be easily generalised onto developing economies such as South Africa, which has a different cultural setting. However, much work is available from other parts of the globe (Fairlie, Zissimopoulos, \& Krashinsky, 2010; Fairlie \& Lofstrom, 2013; Fairlie, 2008, 2012b).

Noting the dearth in context-specific research, the current study fills a gap in this under-researched area by investigating economic opportunities generated by African immigrant entrepreneurs and the challenges they face in conducting business in South Africa. Moreover, the article scrutinizes immigrant SMEs' contributions to the economic growth of the African region. This study contributes to the literature by showing immigrant entrepreneurship as an important contributor to the economic development of the host nation. This was achieved by employing a mixed-methods approach on a sample of 153 surveyed respondents and 12 interviews. Thus, the research objectives are:

1. To determine the perceptions of immigrant entrepreneurs on economic opportunities that they believe their businesses create.

2. To determine gender differences in the perceptions of immigrant businesses' contributions.

3. To investigate the impact that Afrophobia has on economic opportunities created by African immigrant entrepreneurs in South Africa.

This paper is structured as follows: the next section presents the literature review of studies, which discuss the key concepts of immigrant entrepreneurship, economic contributions by immigrant entrepreneurs, and immigrant entrepreneurship in South Africa. Next, we present the theory that underpins this study. Furthermore, the article presents the material and methods in the following format: research paradigm, sample, its description, data collection, data instruments, data analysis, and research ethics. Later, we explain the results and discuss them to identify the empirical dimensions with respect to the said objectives. Lastly, the study ends with concluding remarks about the findings.

\section{LITERATURE REVIEW}

In general, the literature on immigrant entrepreneurship and contributions are unreliable and inconclusive (Tengeh et al., 2012; Tengeh \& Lapah, 2013; Kalitanyi \& Visser, 2014). Though small business and entrepreneurship are widely researched in both developed and developing countries, we cannot say this about immigrant-owned businesses in the latter. Limited studies conducted in South Africa endeavour to address how immigrant entrepreneurs contribute to the South African economy (Kalitanyi \& Visser, 2010; Fatoki \& Patswawairi, 2012; Ngota et al., 2017), while most articles analyse developed countries such as Canada, Australia, the United Kingdom, and the USA (Fairlie, 2008, 2012a; 2012b; 
Fairlie \& Lofstrom, 2014). The following section presents an overview of the literature on immigrant entrepreneurs and economic contributions by immigrant entrepreneurship.

\section{Overview of Immigrant Entrepreneurship}

Immigrant entrepreneurship developed into an important socio-economic singularity, as it plays a vital role in economic development. It spawns jobs through new business ventures that contribute to wealth creation in a country (Kalitanyi \& Visser, 2010; Ngota et al., 2017). Societal inequalities within the host nation may pose structural barriers that prevent immigrants and ethnic minorities from competing with the locals on an equal footing. Some authors (Bogan \& Darity, 2008; Khosa \& Kalitanyi, 2015) establish that it is difficult for immigrants to enter into the labour market due to their residency status in the host country, which makes entrepreneurship a better option. Khosa and Kalitanyi (2015) reveal that immigrants venture into entrepreneurship with the ambition to survive as an alternative means to confronting the harsh discrimination in the labour market of the host nation. In line with the latter, Vinogradov and Elam (2010) posit that discriminatory wages in the employment sector may push immigrants towards self-employment. Nestorowicz (2011) explains that self-employment refers to working for oneself instead of an employer and drawing income from trade or business one operates personally.

\section{Economic Contributions by Immigrant Entrepreneurs}

Some authors of studies about immigrant entrepreneurship (e.g. Chamuorwa \& Mlambo, 2014; Kalitanyi, 2007; Todaro, 1969) state that the impediment of employment for immigrants - particularly African immigrants - in host country labour markets in most economies, in this case, South Africa, has these cohorts make a living in the only alternative of economic fertile grounds: through the establishment of small businesses that sustain them. A significant number of African immigrants successfully apply their entrepreneurial flair in creating businesses that remarkably create new job opportunities for both migrants and locals (Borjas, 1986; Kalitanyi, 2007; Ngota, 2017). Contrary to the unsubstantiated belief held by many South Africans that immigrants from the north steal South African jobs (Kalitanyi \& Visser, 2010). Fairlie (2012a) indicates in a study conducted in the USA that immigrant business owners make important contributions to the US economy. According to Fairlie (2012a), immigrant entrepreneurs start approximately $17 \%$ of all the new businesses in the USA and represent about $13 \%$ of all business owners. About $12 \%$ of the total business income in the USA is generated by immigrant business owners (Fairlie, 2008, 2012b; Saxenian, 1999). Hence, immigrant entrepreneurship in the USA creates new wealth and jobs. There are substantial international publications on immigrant entrepreneurship (e.g. Saxenian, 1991; Razin, 1993; Goetz, 1999; Lewis, 2001; Mubangizi \& Mubangizi, 2005; Fairlie \& Lofstrom, 2014), which focus on the higher likelihood of immigrant than local start-up businesses, the former's contribution on job creation, and their impeding factors in developed countries.

Furthermore, some studies on immigrant entrepreneurial skills in South Africa indicate that African immigrant entrepreneurial activities are catalysts through which entrepreneurial skills are transferred to the locals (Kalitanyi \& Visser, 2014; Ngota, Rajkaran, \& Mang'unyi, 2019; Timberg, 2005). Others associate this with emerging immigrant entrepreneurial factors in developing countries and South Africa in particular (Fatoki \& Patswawairi, 2012; Radipere, 2012; Tengeh et. al., 2012; Khosa \& Kalitanyi, 2015; Asoba \& 
Tengeh, 2016). Waldinger (2002) indicates that some immigrant groups are more entrepreneurial than others. Furthermore, Waldinger (2002) explains that the reasons for being entrepreneurial are related to culture, structure, ethnicity, and the situation of business operation. The literature analysis shows the utmost importance that studies examine the significant relationship further by exploring the economic contributions of African immigrant entrepreneurs, especially in South Africa.

\section{Immigrant Entrepreneurship in South Africa}

Since the 1990s, South Africa witnesses a rising movement of foreign migrants and refugees (Ngota, 2017). Though many primarily came from the Southern African Development Community (SADC) countries, a huge number come from more distant African regions. South Africa's new migration policy has generated considerable controversy within the country. The policy debate focuses on the implications of migration for the national labour market and for the development of a new national immigration policy.

Hypothetically, in terms of economic development and growth, the local economy should include the potential contribution that immigrant entrepreneurs can make to their host locations (Pinkowski, 2009). Although business opportunities are open to all, Pinkowski (2009) contends that it is the immigrants who are likely to produce a greater number of new business start-ups with their associated outcomes. Immigrants are not just fundamentally risk-averse, they believe in their ability to succeed and use their personal savings or even their homes and other personal assets on the line to grow their own businesses, while simultaneously creating employment opportunities for others (Pinkowski, 2009).

The CDE (2004) report shows that the debates about SME development and policy pay too little attention to the potential contribution of immigrant entrepreneurs and, in particular, African immigrant entrepreneurship to the economy. Although the South African government's SME development policy acknowledges the important contribution that SMEs make to economic development, nowhere are immigrants singled out as part of this process (Tengeh, 2007). The Department of Trade and Industry (DTI) categorically states that SMEs play a vital role in economic development because, on the one hand, they enable people to meet their basic needs and survive while, on the other hand, through the growth of the SME sector, surviving firms become small enterprises, thus creating jobs and raising the standard of living for millions of South Africans in urban and rural areas (Ntsika Enterprise Promotion Agency, 2000; Von Broembsen \& Wood, 2005).

Nonetheless, immigrant entrepreneurship should be a vital resource in the host nation's economic development; as such, it should be formally recognised, encouraged, and even nurtured. Debates about immigration and entrepreneurship in South Africa continue in isolation from one another, ignoring the international and local experience, which indicates the important contribution that immigrants make to building a successful culture of entrepreneurship and supplementing the pool of positive role models for would-be South African entrepreneurs (CDE, 2004).

\section{Theoretical Guide}

This paper is anchored in the ethnic entrepreneurship theory (Waldinger, Aldrich, \& Ward, 1990), which seeks to explain immigrant entrepreneurship based on three interactive components; namely, access to opportunities, group characteristics, and emergent strat- 
egies. Opportunity structure describes the market conditions under which immigrant businesses operate, i.e. the market conditions, which may favour products or services orientated towards co-ethnics or to a non-ethnic market. The ease with which immigrant entrepreneurs access business opportunities highly depends on the level of inter-ethnic competition and state policies. For example, in South Africa, the past decade has seen aggressive competition between native-owned small business operators and businesses owned by African immigrants (Liedeman, Charman, Piper, \& Petersen, 2013). Ngota and Rajkaran (2016) describe "Afrophobia" as a range of negative attitudes and feelings to-wards black people or people of black descent around the world. Afrophobia can be viewed as attitudes, prejudices, and behaviours that reject, exclude, and often vilify persons based on the perception that they are outsiders or foreigners to the community, society, or national identity. This form of resentment amongst African immigrant entrepreneurship in South Africa was criticized in recent years with the perception of locals' jealousy towards African immigrants' business prospects. Moreover, immigrant-owned businesses tend to flourish. Apart from the zeal and a culture of prudence displayed by African immigrant entrepreneurs, they usually exploit opportunities for business that present themselves, such as serving the needs of poorer consumers by offering inexpen-sive products anywhere anytime, therefore, meeting their specific demands (Washinyira, 2015). The continuous increase in Afrophobic attacks can severely impact economic contributions from African immigrant-owned businesses in South Africa.

Another dimension of literature in the field of immigrant entrepreneurship posits that entrepreneurial contributions are higher amongst male immigrant entrepreneurs than amongst the female. Evidence from studies in the field of immigrant entrepreneurship represents immigrant women - specifically those of African origin - as additional agents of economic contributions (Bennett \& Dann, 2005; Nkealah, 2011; Nkrumah, 2016; O'Neill \& Viljoen, 2001; Yetim, 2008). Nkrumah (2016) perceives the underrepresentation of immigrant women in most empirical studies as a cultural and political injustice, which removes women from equal representation over the past decades. Explaining it from the cultural perspective, it is a common cultural phenomenon in the Africa continent that men are regarded as breadwinners while women are to look after the house when men are gone. The stereotype has men migrate, leaving behind women and children. Protagonist of the feminist theory differs with the cultural views by arguing that, perhaps because of ignorance and lack of education in many societies in past, put men on high migratory trends than women. Nowadays, education and awareness has been created in many societies which have seen impacts in the migratory trends with many women being part of the process, hence they have been noted to play significant roles in the economic contributions of their host nations (Nkealah, 2011; Nkrumah, 2016).

According to Waldinger et al. (1990), the group characteristics define the predisposing factors, such as selective migration, culture, and aspiration levels. These include the possibility of resource mobilization, ethnic social networks, general organizing capacity, and government policy that constrains or facilitates resource acquisition. Coulthard and Loos (2007) contend that building and managing personal relationships with individuals and firms that surround one's business is important when employing networking tactics to exploit existing opportunities. Sufficient networking can create space for immigrant entrepreneurs to share ideas and solve problems (Khosa \& Kalitanyi, 2015). However, this has 
been complicated by the government through the implementation of stringent regulations on immigrant business owners (Asoba \& Tengeh, 2016). The final component of the model describes the ethnic strategies that emerge from the interaction of opportunities and group characteristics, as ethnic groups adapt to their environments (Waldinger et al., 1990). It has been noted (Aaltonen \& Akola, 2014) that host entrepreneurs can gain new skills in entrepreneurship through interaction among immigrant entrepreneurs. Small businesses owned by immigrants tend to be competitive by adopting niche strategies such as flexibility, high quality of products, and response to the specific needs of customers (Mac \& Bhaird, 2010). With such new ideas and improved product and service offerings, they promote their business. Furthermore, through competitive methods, immigrant entrepreneurs tend to prevent a monopoly in local markets (Mason \& Rown, 2013).

The strong point of the ethnic entrepreneurship theory is that it provides a broader picture of how immigrants explore their host environments. Therefore, this theory fits the current study as one the first studies of its kind to scientifically test the survival and challenges of immigrant entrepreneurship in host countries (Aldrich \& Waldinger, 1990; Habiyakare, Owusu, Mbare, \& Landy 2009; Light, Bhachu, \& Karageorgis, 1989; Waldinger et al., 1990). The current study depicts African immigrants' entrepreneurial flair in a host community. Considering the aforesaid, this study investigated African immigrant entrepreneurs' (SMEs) economic contribution in South Africa. Furthermore, it sought to establish the impact of Afrophobia, which is a major challenge to African immigrants' economic activities (Crush et al., 2013).

\section{MATERIAL AND METHODS}

\section{Research Paradigm}

We undertook an inquiry by using the convergent mixed-methods approach (Creswell, 2014) to ascertain the opinions and experiences of various African immigrant entrepreneurs regarding the contributions they make into the South African economy, with the aim to further inform the research agenda. A quantitative survey design (questionnaire) was used, which ensured variety (Saunders, Lewis, \& Thornhill, 2012) in the sample of immigrants drawn from various countries. Moreover, in-depth qualitative interviews were conducted that complemented the quantitative data findings.

\section{Sample and Its Description}

The target population was all African immigrant entrepreneurs who own businesses in the Eastern Cape Province of South Africa. Immigrants targeted in the study were drawn from different countries; namely, Cameroon, the Democratic Republic of Congo, Ethiopia, Ghana, Nigeria, and Somalia. The sample elements were selected through straightforward random sampling and snowballing techniques from a list of African immigrant small businesses obtained from respondent ethnic groups within the Municipalities and Business Support Centres of selected towns and through referral. The sample comprised 165 foreign participants who own SMEs in the province. A pilot study was conducted on a convenience sample of 13 such owners prior to actual data collection, while face validity, content, and external validity were ensured through a representative sample at a $5 \%$ marginal error. 


\section{Data Collection Methods}

Data was collected through personally administered questionnaire surveys, distributed to and received from participants at an agreed date and time. In-depth interviews were also conducted on a one-on-one basis with 12 respondents. Both questionnaires and in-depth interviews were developed in English as most of the immigrants use the English language as a means of communication. However, in some instances, pidgin English was used, a local dialect mostly employed in the West and Central African states. Pidgin English was used to capture the exact perceptions of immigrant entrepreneurs in their own language. The data was collected from July to September 2016. During that period participants were constantly contacted to complete questionnaires. A personal followup resulted in an increase in response rate.

\section{Data Collection Instruments}

The questionnaire used contains both closed-ended and open-ended items. Questionnaires were used because they are easy to administer to a large population at a low cost, unambiguous, and easily analysed (Zikmund, Babin, Carr, \& Griffin, 2010; Sekaran \& Bougie, 2016). Before adopting the questionnaire, we sought expert views in the business field and used their suggestions to refine questions. The questionnaire had three parts that sought information on business resources, employment, resource challenges, entrepreneurial skills, and transfer of skills. We generated the questions ourself based on the literature. Moreover, the questionnaire contained a section for gathering demographic information on the respondents' age, gender, country of origin, duration of stay in South Africa, and the period of time they own a business. The in-depth interview was generated based on questionnaire items. The alpha $(\alpha)$ reliability coefficient for the questionnaire was above the recommended threshold of 0.7 (Hair, Black, Babin, Anderson, \& Tatham, 2006), which indicates that it had acceptable internal consistency reliability.

\section{Data Analysis}

The data consisted of responses to the survey questionnaires, audio transcripts, and notes taken during the interviews. Firstly, the data collected through questionnaires were checked for omissions, legibility, and consistency in classification; discarding incomplete responses that lacked data; and identifying potential errors in data collection and discussing their implications (Zikmund et al., 2010; Vogt, Vogt, Gardner, \& Haeffele, 2014). Secondly, we transcribed all the audio recordings in pidgin English before translating them into English and, next, we read each transcript to get an overall sense of the whole. Thirdly, we read the transcripts to identify transitions in experience, with each transition signifying a separate unit of meaning. We followed this process to find a deeper meaning in what the respondents said. The redundancies in units of meaning were eliminated so that the remaining units related to one another. Finally, we rephrased answers in a scientific manner and synthesized insights into descriptions of perceptions on how African immigrant entrepreneurs contribute to economic opportunities in the Eastern Cape Province. Themes were captured, coded, and analysed. Using the inductive approach, we achieved patterns, themes, and categories to group similar responses into categories (Creswell, 
2014; Sekaran \& Bougie, 2016). The identification of themes provided depth to the understanding of individual views of immigrant entrepreneurs (Creswell, 2010, p. 256).

\section{Research Ethics}

While engaging with the participants, the study recognised all ethical considerations, as proposed by Sekaran and Bougie (2016). Informed consent was sought from respondents by disclosing the procedures of the survey and how would be later used, hence the importance of participation. The study used fictitious names to typify transcribed data wherever necessary.

\section{RESULTS AND DISCUSSION}

Upon analysing data from all 165 completed returned surveys and the interviews on the contributions of African immigrant small businesses in South Africa, several primary findings emerged. These findings are now presented and then discussed in relation to the theoretical framework of the study. However, first, we present the socio-demographic information.

\section{Sample Characteristics}

We noted that (Table 1) the participants came from varied cultural, geographic, and linguistic backgrounds, including Nigeria, Cameroon, Ethiopia, Ghana, Somali, and the Democratic Republic of Congo. Over $69.9 \%$ were male, $68.6 \%$ were $31-40$ years old, and $35.3 \%$ were from Nigeria. The majority, $54.9 \%$ lived in South Africa for 5-10 years. The majority, $58.8 \%$ operated their businesses $5-10$ years, while $24.8 \%$ ran businesses for less than five years, with a meagre $1.3 \%$ for more than 20 years.

\section{Form of Entrepreneurship and Economic Contributions}

The forms of entrepreneurship and their economic impact on the economy was analyzed inferentially. Figure 1 shows that most participants earned a living by engaging in sole proprietorship. More particularly, $95.4 \%$ of the respondents were individual owners of businesses, $3.3 \%$ ran family businesses, and only $1.3 \%$ were in partnership. Researchers like Radipere (2012) show that the most common type of business ownership among immigrants involves sole proprietorship (57.8\%) and partnership (25.4\%), while the least common is a close corporation and private companies ( $14.7 \%$ and $2 \%)$. The majority of the participating entrepreneurs (52.9\%) offered services, $41.8 \%$ traded, whilst $5.2 \%$ manufactured. Therefore, it was evident that the service and businesses were the most preferable options among African immigrant entrepreneurs.

\section{Economic Opportunities Created}

The researchers deemed necessary to determine which opportunities African immigrant entrepreneurs created in the South African economy. Figure 2 reveals that competition was the most important contribution (approximately $73.9 \%$ ), followed by innovation (about $17 \%)$. Technology was the third factor $(9.2 \%)$. 
Table 1. Participants' background attributes

\begin{tabular}{|c|c|c|c|}
\hline Background attribute & Value label & Frequency & Percentage \\
\hline Gender & $\begin{array}{c}\text { Male } \\
\text { Female }\end{array}$ & $\begin{array}{c}107 \\
46\end{array}$ & $\begin{array}{l}69.9 \\
30.1\end{array}$ \\
\hline Age & $\begin{array}{c}\quad<20 \\
21-30 \text { years } \\
31-40 \text { years } \\
41-50 \text { years } \\
51-60 \text { years }\end{array}$ & $\begin{array}{c}1 \\
18 \\
105 \\
27 \\
2\end{array}$ & $\begin{array}{c}0.7 \\
11.8 \\
68.6 \\
17.6 \\
1.3\end{array}$ \\
\hline Country of origin & $\begin{array}{c}\text { Nigeria } \\
\text { Cameroon } \\
\text { Ethiopia } \\
\text { Ghana } \\
\text { Somali } \\
\text { DRC } \\
\text { Other }\end{array}$ & $\begin{array}{c}54 \\
41 \\
5 \\
27 \\
1 \\
13 \\
18\end{array}$ & \begin{tabular}{c|}
35.3 \\
26.8 \\
3.3 \\
17.6 \\
0.7 \\
8.5 \\
7.8
\end{tabular} \\
\hline Duration of stay in South Africa & $\begin{array}{c}<5 \text { years } \\
5-10 \text { years } \\
11-15 \text { years } \\
>15 \text { years }\end{array}$ & $\begin{array}{c}24 \\
84 \\
39 \\
6\end{array}$ & $\begin{array}{c}15.7 \\
54.9 \\
25.5 \\
3.9\end{array}$ \\
\hline Years of business operation & $\begin{array}{c}<5 \text { years } \\
5-10 \text { years } \\
11-15 \text { years } \\
16-20 \text { years } \\
\quad>20\end{array}$ & $\begin{array}{c}38 \\
90 \\
21 \\
2 \\
2\end{array}$ & $\begin{array}{c}24.8 \\
58.8 \\
13.7 \\
1.3 \\
1.3\end{array}$ \\
\hline
\end{tabular}

Source: own elaboration based on the survey $(n=153)$.

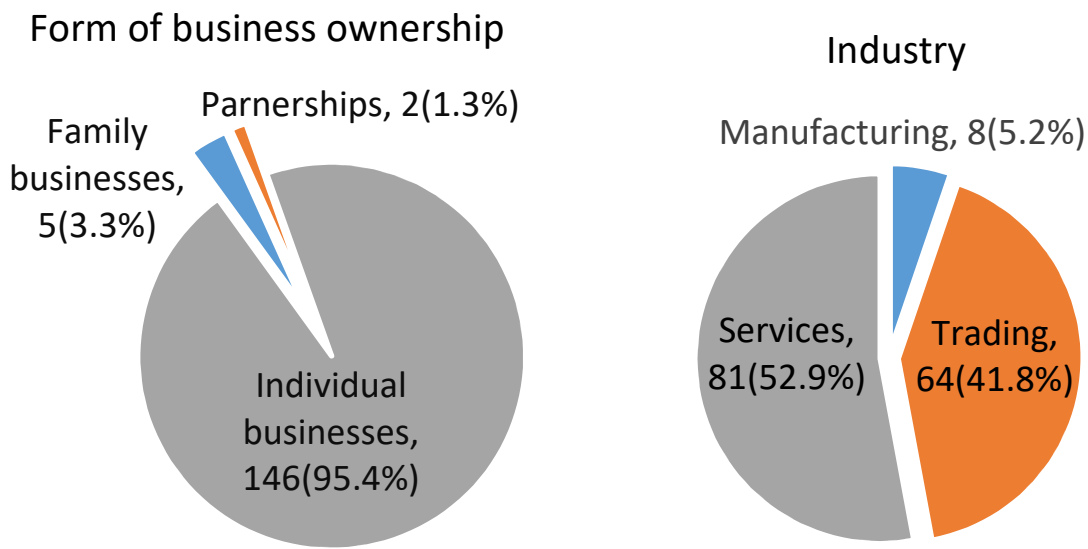

Figure 1. Forms of entrepreneurship and industry

Source: own elaboration based on the survey $(n=153)$. 
Economic contributions

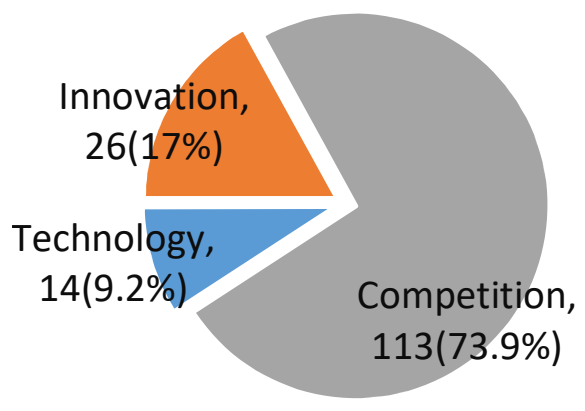

Contribution to GNI

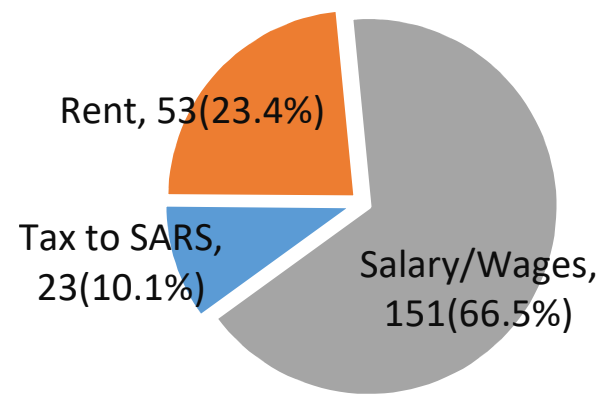

Figure 2. Socio-economic contributions

Source: own elaboration based on the survey $(n=153)$.

To corroborate the quantitative findings, we use the following respondents' quotes to highlight each point.

"I think my business offers competition in the business environment as clients will turn to compare the best prices for goods, we provide to those provided by competitors" (P\#01).

"as I try to bring in new knowledge by not only relying on the traditional routine operations as the other big garages will do" (P\#02).

"I believe I offer the best quality of food I serve to my customers compared to what is provided by my competitors.... the evidence is seen as customers keep on coming here for the food" (P\#04).

Based on the outcomes, other important facets with respect to innovation and technological development pertinent to business growth, maintenance, and survival were highlighted by respondents, which they indicated as important. The following excerpts complement the quantitative findings and cement the importance of innovation among SMEs operated by African immigrant entrepreneurs:

"I can say that my business offers innovation and competition in the business environment. I try to make things differently by shifting away from the normal routine applied in sophisticated workshops and bring in new ways of doing things" (P\#05).

"We are involved in the construction industry and I think our business offers innovation by bringing in and applying new designs, which our clients love so much" (P\#06).

"There is innovation in our manufacturing business.... Since we deal with product development, we have to bring in new product lines which we distribute to certain of our outlets who like and buy them... keeping us competitive in business all this while" (P\#03). 
"I believe that my business offers innovation as it brings creative knowledge and helps equip the community with services on technology" (P\#07).

\section{Contributions to the Gross National Income (GNI)}

Regarding how African immigrant-owned businesses contribute to the economic growth of the province and the country as a whole, the results in Figure 2 demonstrate that contributions are made to the GNI through payment of salary/wages to employees (66.5\%), rents for businesses premises (23.4\%), and taxes to the South African Revenue Service (SARS; $10.1 \%$ ). These findings are corroborated by findings from personal interviews, for example, when asked on how their businesses contribute to the GNI of the province, the interviewees answered:

"Yes, my business pay tax to the SARS, I also pay salaries/wages to my employees and rent to the owner of the premises, in which I operate my business" (P\#01).

"Sure, my business pays salaries to my employees. I also pay some money every month in the form of rents to a representative who says he is a municipal agent (street committee leader) since I operate my business in a container" (P\#08).

Moreover, in order to determine the differences in the gender perception of immigrants' businesses contributions a cross-tabulation was done as shown in Table 2. Table 2 shows that the majority $(144 ; 94.1 \%)$ of the respondents stated that their entrepreneurial activities contribute 'very positively' to the economy, while a few $(0.7 \%)$ remained 'neutral.'

Table 2. Cross-tabulation between gender and immigrants' businesses contributions

\begin{tabular}{|l|l|c|c|c|c|}
\hline \multirow{2}{*}{ Gender } & \multirow{2}{*}{ Variable } & \multicolumn{2}{|c|}{ Immigrants' businesses contributions to the SA economy } & \multirow{2}{*}{ Total } \\
\cline { 3 - 6 } & & Very positive & Positive & Neutral & \\
\hline \multirow{3}{*}{ Male } & Count & 102.0 & 5.0 & 0 & 107.0 \\
\cline { 2 - 6 } & Expected Count & 100.7 & 5.6 & 0.7 & 107.0 \\
\cline { 2 - 6 } & \% within Gender & $95.3 \%$ & $4.7 \%$ & $0 \%$ & $100.0 \%$ \\
\hline \multirow{3}{*}{ Female } & Count & 42.0 & 3.0 & 1.0 & 46.0 \\
\cline { 2 - 6 } & Expected Count & 43.3 & 2.4 & 0.3 & 46.0 \\
\cline { 2 - 6 } & \% within Gender & $91.3 \%$ & $6.5 \%$ & $2.2 \%$ & $100.0 \%$ \\
\hline \multirow{3}{*}{ Total } & Count & 144.0 & 8.0 & 1.0 & 153.0 \\
\cline { 2 - 6 } & Expected Count & 144.0 & 8.0 & $0.7 \%$ & $100.0 \%$ \\
\cline { 2 - 6 } & \% within Gender & $94.1 \%$ & $5.2 \%$ & 1.0 & 153.0 \\
\hline
\end{tabular}

Source: own elaboration based on the survey $(n=153)$.

The association between gender perception of African immigrant entrepreneurs' contributions to the South African economy was analysed using Pearson Chi-square test statistics, in which gender was the independent variable while perceived business contributions the dependent variable, as illustrated in Table 3.

Chi-square statistic test $\left(X^{2}\right)$ of the difference between gender perceptions regarding immigrant businesses' contributions to South Africa's economy resulted in a $p$-value (0.274). Table 3 shows that there is no variance in their perceptions, implying that no difference existed between men and women in views about their business influence on the economy. 
Table 3. The relationship between gender and perceived business contributions

\begin{tabular}{|l|c|c|c|}
\hline \multicolumn{1}{|c|}{$\mathrm{X}^{2}$ tests } & Value & Degree of freedom & P-value (2-sided) \\
\hline Pearson $X^{2}$ & $2.592^{\text {a }}$ & 2 & 0.274 \\
\hline Likelihood Ratio & 2.661 & 2 & 0.264 \\
\hline No of Valid Cases & 153.000 & - & - \\
\hline
\end{tabular}

Source: own elaboration based on the survey $(n=153)$.

\section{Challenges and Consequences to Immigrant Entrepreneurship in South Africa}

Afrophobia is the key challenge that adversely impacts immigrant entrepreneurship in South Africa (Khosa \& Kalitanyi, 2014; Mutambanengwe, 2013, Khosa \& Kalitanyi, 2015). Table 4 shows that most participants attributed this to unemployment (43.4\%), jealousy (30.9\%), disregard for the rule of law $(22.3 \%)$, or rampant corruption (3.5\%). These results are not different from those from the interviews, as interviewees shared similar sentiments. The following quotes reinforce test results:

"In my humble opinion, I believed that the root causes of this violence perpetrated against African immigrant entrepreneurs are... unemployment; stealing, jealousy, and looting are the brain behind the violent attacks against us" (P\#04).

"I think jealousy and corruption are the main causes of Afrophobia because the South Africans feel that the other nationals are doing well in their businesses and also, they take advantage to take from these immigrants falsely" (P\#08).

"Jealousy is the main cause of Afrophobia because the South Africans feel others from outside are better off than them. Also, as a foreign employer always pay your employees especially the South African nationals at the right time that you promised to pay them because failure of this circumstance also is the secondary cause of such attacks" (P\#05).

"I think hatred and jealousy by some South African nationals towards their African brothers/sisters with a criminal intention" (P\#09).

"I think unemployment is the main cause of Afrophobia because if everyone has something to do, people will think less of such violence" (P\#01).

The researchers were interested to explore the effect that perceived attacks on African immigrants businesses will have on the economy as a whole. As reflected in Table 4 , the majority (95.4\%) of the participants stated that continuous attacks will force them to close down their businesses, while 3.9\% mentioned that in the event that their businesses are closed down, it would resort to not providing jobs to locals. The resulting effects on business are inadequate skills transfer, a reduction in foreign direct investment, and increased unemployment. Such consequences negatively affect both the informal and formal sectors (Tshishonga, 2015). Statements such as the following epitomise the effects of violence:

"In an event of Afrophobia directed towards immigrant businesses... immigrants owning small businesses will be affected in that if their businesses are looted and burnt down, as it was witnessed recently in some parts of the country... they will 
be forced to close them down permanently... This will affect the people that are employed by these businesses. Therefore, it will affect contributions made to the GDP of the country" (P\#06).

"If I close down my business today, because of such attacks, it means that even the people I have employed today will become unemployed as a direct consequence" (P\#10).

"In my opinion, I think that the close down of foreign immigrants owned businesses can lead to job losses thereby increasing the level of unemployment in South African" (P\#11).

"If some of these businesses owned by the immigrants are closed down, it will definitely mean that knowledge and skills transmission to the South Africans by such businesses would not be possible" (P\#03).

"Looking at what is happening, Afrophobic attacks directed towards African immigrants can threaten foreign investments... as investors will be scared to bring in their investments into such an environment, where the law is not strengthened on such perpetrated acts... This will definitely have a negative impact on the country's economy in the long run" (P\#01).

"Afrophobia can threaten foreign investments as investors will be scared to bring their investments into such an environment, where the law is not strengthened on such perpetrated acts" (P\#03).

Table 4. Causes of attacks and their consequences on economic opportunities

\begin{tabular}{|l|l|c|c|}
\hline \multicolumn{1}{|c|}{ Variables } & \multicolumn{1}{|c|}{ Value label } & Frequency & Percentage \\
\hline \multirow{4}{*}{$\begin{array}{l}\text { Causes } \\
\text { of violence }\end{array}$} & Unemployment & 111 & 43.4 \\
\cline { 2 - 4 } & Jealousy & 79 & 30.9 \\
\cline { 2 - 4 } & Failure to uphold justice & 57 & 22.3 \\
\cline { 2 - 4 } & Corruption & 5 & 1.8 \\
\cline { 2 - 4 } & Others & 4 & 1.6 \\
\hline \multirow{2}{*}{$\begin{array}{l}\text { Perceived } \\
\text { consequences }\end{array}$} & Business close down & 147 & 95.5 \\
\cline { 2 - 4 } & Refusal to employ South Africans in retaliation & 6 & 3.9 \\
\cline { 2 - 4 } & Others & 1 & 0.6 \\
\hline
\end{tabular}

Source: own elaboration based on the survey $(n=153)$.

\section{DISCUSSION}

Regarding the contextual factors, especially socio-demographic, the findings highlight that African immigrant entrepreneurs 31-40 years old are highly involved in entrepreneurship. The majority of this age group consists of Nigerian nationals, followed by Cameroonians. The middle-aged population may result from youthful exuberance when most young people venture abroad in search of greener pastures. It appears this sample is typical of startups owned by young immigrant entrepreneurs who wish to gain economic mileage or better chances of survival (Habiyakare et al., 2009). It is also interesting to note that there were many younger male immigrant entrepreneurs who operate businesses in South Africa than female. These findings corroborate those of Khosa and Kalitanyi (2014) who affirm that the majority of African immigrant entrepreneurs are mostly middle-aged men. 
This gender imbalance is possibly a cultural factor because African men are more open to this sort of high-risk venture than women. Traditionally, African men are more involved in activities that financially support their families, while women are more involved in household activities. Therefore, there is a strong interplay between age and economic contributions, making it the key economic contributing factor.

Moreover, we ascertained from the inferential statistics presented in Figure 1 that the majority of African immigrant entrepreneurs followed sole proprietorship, with only a few partnered with others. This may be the result of limited start-up capital available at the establishment stage and, as such, each business must be carefully nurtured, groomed, and then developed by the owner (Tengeh et al., 2012). Radipere (2012) affirms that sole proprietorship is the most common type of business ownership amongst immigrants who operate small businesses, as the burden to establish, grow, and develop it is perhaps manageable. Most sole proprietors engage in service businesses and trading to generate economic benefits as against a limited number in manufacturing, affirming the capital deficiency theory (Tengeh et al., 2012).

Furthermore, economic opportunities created by African immigrant entrepreneurs were also determined, and our analysis showed that economic competition and innovation were strongly initiated in the business environment. Ntsika Enterprise Promotion Agency (2012) affirms that - with such high level of competition - small businesses owned by African immigrant entrepreneurs tend to drive away monopoly in the local markets by providing specialized goods and services at competitive costs. This was corroborated by qualitative data from our interview excerpts, which strongly affirmed that immigrant entrepreneurs brought innovation and created competition in the business environment. Immigrants utilise their skills and capacities to earn a living (Kreitzer, 2012) by effectively applying those skills (Kalitanyi \& Visser, 2010). This has been highlighted in some studies (Kalitanyi \& Visser, 2010; Tengeh et al., 2012) that show immigrant entrepreneurs to have the ability to bring about technological developments, hence tremendously contributing to the growth of technology in a country while also playing a role in the reduction of inequality and poverty.

The study indicated that African immigrant contributed to the GNI of South African as a host nation. This is supported by studies conducted by Liebig and Mo (2013) and OECD (2016), which show that the GNI impact of immigrants is the highest in many developed countries. The study indicated that African immigrant contributed to the GNI of South Africa as a host nation. This is supported by studies conducted by Liebig and Mo (2013), and OECD (2016), which show that the GNI impact of immigrants is the highest in many developed countries, for example, countries such as Switzerland and Luxembourg witnessed the highest net benefits estimated at about $2 \%$ of GNI contributed by immigrants. This indicates the positive contributions that would emanate from entrepreneurship to a developing nation such as South Africa if immigrant entrepreneurship is supported and nurtured.

Gender differences in the perception of immigrant businesses' contribution found a positive contribution from both men and women. From the Pearson Chi-square test (Table 3 ) on variables, gender and economic contribution emerged as variables, since the $p$-value was 0.274 with a 2 degree of freedom, showed that there were no significant differences in the perception of African immigrant contributions amongst genders. 
Fairlie (2012a; 2012b) states that immigrant business owners make important contributions to the economy of their host countries.

The challenges that immigrant entrepreneurs encounter in the host nation - Afrophobia - emerges as a factor that deters African immigrant entrepreneurs from business. This finding corroborates a previous study by De Jager (2013) who demonstrates that jealousy of the success of foreign business contributes immensely to Afrophobic attacks on African immigrant-owned ventures. These sentiments were equally shared among interviewees. Moreover, other previous studies confirm such findings (Bordeau, 2010), in which fear and jealousy related to employment and income were blamed for Afrophobic attacks on African immigrants. The lack of knowledge and understanding of how foreigners find money to start their businesses fuels jealousy (Bordeau, 2010). Attacks on African immigrant-owned enterprises have serious implications for the economy.

Researchers (IOM, 2006; Radipere, 2012) indicate that South Africans should view immigrant entrepreneurs as contributors to the economy. Moreover, Khosa and Kalitanyi (2015) affirm that country initiatives that support immigrant entrepreneurship lead to economic triumph and work creation.

\section{CONCLUSIONS}

The current study investigated the economic contributions that African immigrant entrepreneurs make to the South African economy, but also the challenge of Afrophobia and its consequences. The study sheds light on an area deficient in empirical research. Our analysis of the economic contributions created by African immigrant entrepreneurs produced the following results: African immigrant entrepreneurs create such economic opportunities as competition that drives away monopoly, innovations, and technology. Moreover, African immigrants' SMEs contribute to the economic growth of the province under scrutiny through employment, rental payments, and tax remissions. While respondents in the survey were overall positive and optimistic, they still noticed challenges that impede economic growth: Afrophobic tendencies and attacks on African immigrant businesses that adversely impact their continuity and survival. Consequently, Afrophobia emerged as harmful to job creation and socio-economic well-being of a community. We conclude that African immigrant entrepreneurs clearly influence economic growth in a positive way. There is a need to reform immigration policies in order to minimize existing tensions and stimulate local skills development, technology development and transfer, new business opportunities, and improve the transformation of the country into a globalised economy.

Despite the fact that the study is limited by its South African focus and investigative nature, which restricts the possibility of generalisations, we hope that it lays a foundation for further examination of immigrants' economic contributions in the SME context, which may make use of available panel data with superior data analysis approaches. These techniques may shed more light on the economic contributions of African immigrant-owned SMEs. The potential also exists to replicate the study in other cultural contexts and on a larger scale. 


\section{REFERENCES}

Aaltonen, S., \& Akola, E. (2014). Lack of trust - the main obstacle for immigrant entrepreneurship? Retrieved from http://www.pyk2.aalto.fi/ncsb2012/aaltonen.pdf on March 15, 2015.

Aldrich, H., \& Waldinger, R. (1990). Ethnicity and Entrepreneurship. Annual Review of Sociology, $16,111-135$.

Anderson, S., \& Platzer, M. (2006). American Made: The Impact of Immigrant Entrepreneurs and Professionals on U.S. Competitiveness. Arlington, VA: National Venture Capital Association.

Asoba, S.N., \& Tengeh, R. (2016). Analysis of start-up challenges of African immigrant-owned businesses in selected craft markets in Cape Town. Environmental Economics, 7(2), 93-105.

Beaujot, R., Maxim, S., \& Zhao, J. (1994). Self-employment among immigrants: a test of the blocked mobility hypothesis. Canadian Studies in Population, 21(2), 81-96.

Bennett, R., \& Dann, S. (2005). The changing experience of Australian female Entrepreneurs. Gender Work and Organization, 7(2), 75-83.

Bogan, V., \& Darity, W. (2008). Culture and entrepreneurship? African American and immigrant selfemployment in the United States. Journal of Socio-Economics, 37(1), 1999-2019.

Bordeau, J. (2010). Xenophobia: The Violence of Fear and Hate. New York: The Rosen Publishing Group.

Borjas, G. (1990). Friends or Strangers: The Impact of Immigrants on the U.S. Economy. New York: Basic Books.

Borjas, G. (1986). The self-employment experience of immigrants. Journal of Human Resources, 21(4), 485-506.

Brewer, J., \& Gibson, S. (2014). Necessity entrepreneurs' microenterprise education and economic development. Cheltenham, UK: Edward Elgar Publishing Ltd.

CDE. (2004). Key to Growth: Supporting South African emerging entrepreneurs. Johannesburg.

Chamuorwa, W., \& Mlambo, C. (2014). The unemployment impact of immigration in South Africa. Mediterranean Journal of Social Sciences, 5(20), 2-6.

Coulthard, M., \& Loos, J. (2007). Networking, the link in firm based entrepreneurial operation (EO) performance model. Retrieved from www.buseco.monash.edu.au/mgt/staff/coulthard.max.html on September 18, 2015.

Creswell, J. (2010). Mapping the developing landscape of mixed methods research. In A. Tashakkori \& C. Teddlie (Eds.), SAGE handbook of mixed methods in social and behavioural research (2nd ed., pp. 45-68). Thousand Oaks, CA: Sage.

Creswell, J. (2014). Qualitative, quantitative and mixed methods approach (4th ed.). Thousand Oaks, CA: Sage.

Crush, J., Ramachandran, S., \& Pendleton, W. (2013). Soft targets: Xenophobia, public violence and changing attitudes to migrants in South African after May 2008. Southern African Migration Programme, 32(2), 25-29.

De Jager, S. (2013, May 6). Xenophobia 'has roots in jealousy.' The Herald, p. 2. Retrieved from www.peherald.com/news/article/14555 on May 15, 2019.

DeLancey, R. (2014). Entrepreneurship and immigration: a study of Africans in the Korean economy. International Journal of Knowledge and Innovation in Business, 1(1), 1-20.

Dele-ljagbulu, J.O., \& Chirau, R. (n.d.). Investigating the role of African immigrant-owned small businesses in employment creation in South Africa. Retrieved from www.nationalgovernment.co.za on May, 15, 2019. 
Douglas, E., \& Shepherd, D. (2002). Self-employment as a Career Choice: Attitudes, Entrepreneurial Intentions, and Utility Maximization. Entrepreneurial Theory and Practice, 26(3), 81-90.

Ekwulugo, F. (2006). Entrepreneurship and SMEs in London (UK): evaluating the role of black Africans in this emergent sector. Journal of Management Development, 25(1), 65-79. https://doi.org/10.1108/02621710610637972

Fairlie, R.W., Zissimopoulos, J., \& Krashinsky, H. (2010). The International Asian Business Success Story: A Comparison of Chinese, Indian, and Other Asian Businesses in the United States, Canada, and the United Kingdom. In J.L. \& A. Shoar (Ed.), International Differences in Entrepreneurship (pp. 179-208). Chicago: University of Chicago Press and National Bureau of Economic Research.

Fairlie, R.W., \& Lofstrom, M. (2014). Immigration and Entrepreneurship. In B. Chiswick, \& P. Miller (Ed.). Handbook on the Economics of International Migration. Elsevier.

Fairlie, R., \& Lofstrom, M. (2013). Immigration and entrepreneurship (No. 7669). Bonn.

Fairlie, R. (2008). Estimating the Contribution of Immigrant Business Owners to the U.S. Economy. Washington, DC: Small Business Administration, Office of Advocacy.

Fairlie, R. (2012a). Immigrant Entrepreneurs and Small Business Owners, and their Access to Financial Capital. Retrieved from www.sba.gov/sites/default/files/rs396tot.pdf on March 15, 2015.

Fairlie, R. (2012b). Immigrant entrepreneurs and small business owners and their access to financial capital. Economic Consulting Santa Cruz, 9(1), 1-46.

Fatoki, O., \& Patswawairi, T. (2012). The motivations and obstacles to immigrant entrepreneurship in South Africa. Journal of Social Sciences, 32(2), 133-142.

Fatoki, O. (2014). The entrepreneurial alertness of immigrant entrepreneurs in South Africa. Mediterranean Journal of Social Sciences, 5(23), 1-5.

Friedberg, R.M., \& Hunt, J. (1995). The Impact of Immigrants on Host Country Wages, Employment and Growth. Journal of Economic Perspective, 9(2), 23-44.

Goetz, S.J. (1999). Migration and local labour markets. The Web Book of Regional Science. Penn: Penn State University.

Habiyakare, E., Owusu, R.A., Mbare, O., \& Landy, F. (2009). Characterising African immigrant entrepreneurship in Finland. In S.P. Sigué (Ed.), Repositioning African business and development for the 21st Century. Peer-Reviewed Proceedings of the 10th Annual International Conference Held at the Speke Resort \& Conference Centre. Kampala - Uganda: Makerere University Business School.

Hair, J.F., Black, W.C., Babin, B.J., Anderson, R.E., \& Tatham, R. (2006). Multivariate data analysis (6th ed.). Singapore: Prentice-Hall.

Hart, D.M., \& Acs, Z. (2011). High-Tech Immigrant Entrepreneurship in the United States. Economic Development Quarterly, 25(2), 116-129.

Hohn, M. (2012). Immigrant Entrepreneurs Creating Jobs and Strengthening the Economy. Washington, DC: Immigrant Learning Centre.

Hunt, J., \& Gauthier-Loiselle, M. (2010). How Much Does Immigration Boost Innovation?. American Economic Journal: Macroeconomics, 2(2), 31-56.

Hunter, N., \& Skinner, C. (2003). Foreign street traders working in inner-city Durban: Local government policy challenges. Urban Forum, 14(4), 309-331.

IOM. (2006). Integration in today's mobile world. Retrieved from IOM website: http://www.publications.iom.int/bookstore/WMR_2006_English on May 15, 2016.

Kalitanyi, V., \& Visser, K. (2010). African Immigrants in South Africa: Job takers or Job creators?. South African Journal of Economic and Management Sciences, 13(4), 376-390.

Kalitanyi, V., \& Visser, K. (2014). Migration and migrant entrepreneurial skills in South Africa: Assets 
or liabilities?. Mediterranean Journal of Social Sciences, 5(14), 147-158.

Kalitanyi, V. (2007). Evaluation of employment creation by African immigrants entrepreneurs for unemployed South Africans in Cape Town. University of the Western Cape.

Khosa, R.M., \& Kalitanyi, V. (2014). Challenges in operating micro-enterprises by African foreign entrepreneurs in Cape Town, South Africa. Mediterranean Journal of Social Sciences, 5(10), 205-215.

Khosa, R.M., \& Kalitanyi, V. (2015). Migration reasons, traits and entrepreneurial motivation of African immigrant entrepreneurs Towards an entrepreneurial migration progression. Journal of Enterprising Communities: People and Places in the Global Economy, 9(2), 132-155.

Kim, Y., Park, M., \& Wier, B. (2012). Is earnings quality associated with corporate social responsibility?. The Accounting Review, 87(3), 761-796. https://doi.org/10.2308/ accr-10209

Kongolo, M. (2010). Job creation versus job shedding and the role of SMEs in economic development. Journal of Business, 4(11), 2288-2295.

Kreitzer, L. (2012). Social work in Africa: Exploring culturally relevant education and practice in Ghana. Calgary-Alberta: University of Calgary Press.

Lewis, M.J. (2001). Railways in the Greek and Roman World. In A. Guy \& J. Rees (Eds.), Early Railways: A Selection of Papers from the First International Early Railways Conference (pp. 8-19). London: Newcomen Society.

Liebig, T., \& Mo, J. (2013). The Fiscal Impact of Immigration in OECD Countries: International Migration Outlook 2013. Retrieved from OECD Publishing Paris website: http://www.dx.doi.org/10.1787/migr_outlook-2013-6-en on June 24, 2016.

Liedeman, R., Charman, A., Piper, L., \& Petersen, L. (2013). Why are Foreign Run Spaza Shops More Successful? The Rapidly Changing Spaza Sector in South Africa. Retrieved from www.econ3x3.org/sites/default/files/articles/Liedeman\%25202013\%2520Spaza\%2520shops\%25 20FINAL on July 24, 2015.

Light, I., Bhachu, P., \& Karageorgis, S. (1989). Immigrant and entrepreneurship. Los Angeles: University of California Press.

Mabadu, R. (2014). The Role of Social Networks in the Creation and Development of Business among African Immigrants in Madrid Area (Spain). Journal of Small Business and Entrepreneurship Development, 2(3), 27-46.

Mac, A.N., \& Bhaird, C. (2010). Resourcing Small and Medium-Sized Enterprises: A Financial Growth Life Cycle. New York: SPI Publisher Service.

Maharaj, B. (2002). Economic refugees in post-apartheid South Africa Assets or liabilities? Implications for progressive migration policies. Socio-Economic Journal, 56(5), 47-57.

Marchand, K., \& Siegel, M. (2014). World migration report 2015: immigrant entrepreneurship in cities: Background Paper (No. 5463). Washington, DC.

Mason, C., \& Rown, R. (2013). Creating a good public policy to support high growth firm. Small Business Economics, 40(2), 211-225. https://doi.org/10.1007/s11187-011-9369-9

Mubangizi, J.C., \& Mubangizi, B. (2005). Poverty, human rights law and socio-economic realities in South Africa. Development Southern Africa, 22(2), 278-290.

Mutambanengwe, F. (2013). Post-migration experiences of Zimbabwean in Pietermaritzburg, South Africa. University KwaZulu Natal, Pietermaritzburg.

Nestorowicz, J. (2011). Known knowns and known unknowns of the immigrant self-employment selected issues. Journal of Socio-Economics, 45(2), 1-79.

Ngota, B.L., Rajkaran, S., Balkaran, S., \& Mang'unyi, E. (2017). Exploring the African Immigrant Entrepreneurship - Job Creation Nexus: A South African Case Study. International Review of 
Management and Marketing, 7(3), 143-149.

Ngota, B.L., Rajkaran, S., \& Mang' unyi, E. (2019). African Immigrant Entrepreneurship: A Catalyst For Skills Transfer, 25(1), 1-20.

Ngota, B.L., \& Rajkaran, S. (2016). Challenges facing African Immigrant entrepreneurs: A case of South Africa. Balti: LAP LAMBERT Academic Publishing.

Ngota, B.L. (2017). Economic opportunities created by African immigrant entrepreneurs in the Eastern Cape. Walter Sisulu University.

Nkealah, N. (2011). Commodifying the female body: Xenophobic Violence in South Africa. Africa Development, 2, 123-135.

Nkrumah, A. (2016). Ghanaian Female Immigrant Entrepreneurs in Canada: Experiences, Challenges, and Coping Strategies. Open Journal of Social Sciences, 4, 59-78. https://doi.org/10.4236/jss.2016.410005

Ntsika Enterprise Promotion Agency. (2000). State of Small Business in South Africa: Annual Review. Pretoria.

Ntsika Enterprise Promotion Agency. (2012). State of small business development in South Africa 1995. Retrieved from www.polity.org.za/govdoc/whitepaper/smallbiz.html?rebookmark=1 on April 27, 2015.

O'Neill, R.C., \& Viljoen, L. (2001). Support for female entrepreneurs in South Africa: Improvement or decline?. Journal of Family Ecology and Consumer Sciences, 29(2001), 37-44.

OECD. (2016). Renewing the skills of ageing workforces: The role of migration, international migration outlook 2016.

Ojo, S., Nwankwo, S., \& Gbadamosi, A. (2013). African diaspora entrepreneurs: navigating entrepreneurial spaces in 'home' and 'host' countries. Entrepreneurship and Innovation, 14(4), 289-299. https://doi.org/10.5367/ijei.2013.0126

Ojong, V. (2006). The socio-economic impact of African migrant women's entrepreneurial activities in South Africa. Africanus, 32(2), 142-153.

Pinkowski, J. (2009). Challenges and promises for Immigrant Entrepreneurship in Dublin. Report. City of Dublin.

Portes, A., \& Zhou, M. (1996). Self-employment and the earnings of immigrants. American Sociological Review, 61(2), 219-230.

Radipere, N.S. (2012). An analysis of local and immigrant entrepreneurship in the South African small enterprise sector (Gauteng Province). University of South Africa.

Razin, E. (1993). Immigrant Entrepreneurs in Israel, Canada and California. The American Behavioural Scientist, 42(9), 98.

Saunders, M., Lewis, P., \& Thornhill, A. (2012). Research Methods for Business Students (6th ed.). Pearson.

Saxenian, A. (2002). Brain Circulation: How high-skill immigration makes everyone better off. The Brookings Review Winter, 20(1), 28-31.

Saxenian, A. (1991). Aliens, Asian Americans, Immigration, Corporate management. Wall Street Journal New York, 9(2), 6.

Saxenian, A. (1999). Silicon Valley's New Immigrant Entrepreneurs. San Francisco.

Sekaran, U., \& Bougie, R. (2016). Research methods for business: A skill-building approach (7th ed.). West Sussex: John Wiley \& Sons Ltd.

Smith, Y., \& Watkins, J. (2012). A literature review of SME risk management practices in South Africa. African Journal of Business Management, 6(21), 6324-6330. 
Tengeh, R.K., Ballard, H., \& Slabbert, A. (2012). Financing the start-up and operation of immigrantowned businesses: The path taken by African immigrants in the Cape Town metropolitan area of South Africa. African Journal of Business Management, 6(9), 4666-4676.

Tengeh, R.K., \& Lapah, C. (2013). The migratory trajectories of the post-1994 generation of African immigrants to South Africa: An empirical study of street vendors in the Cape Town Metropolitan Area. Medical Journal of Social Science, 4(4), 2039-2117.

Tengeh, R.K. (2007). A business framework for the effective start-up and operation of the area. South Africa. Cape Peninsula University of Technology.

Thomas, K.J.A., \& Inkpen, C. (2013). Migration dynamics, entrepreneurship, and African development: lessons from Malawi. International Migration Review, 47(4), 844-873. https://doi.org/10.1111/imre.12052

Timberg, C. (2005). Refugees with hopes, skills find opportunity in South Africa (No. A21). Washington, DC.

Todaro, M. (1969). A model of labour migration and urban unemployment in less developed countries. American Economic Review, 60, 138-148.

Tshishonga, N. (2015). The impact of xenophobia-Afrophobia on the informal economy in Durban CBD, South Africa. The Journal for Transdisciplinary Research in Southern Africa, 11(4), 163-179.

Turkina, E., \& Thai, M.T. (2013). Social capital, networks, trust and immigrant entrepreneurship: A cross country analysis. Journal of Enterprising Communities: People and Places in the Global Economy, 7(2), 108-124.

Urban, B., \& Naidoo, R. (2012). Business sustainability: Empirical evidence on operational skills in SMEs in South Africa. Journal of Small Business and Enterprise Development, 19(1), 146-163. https://doi.org/10.1108/14626001211196451

Vertovec, S. (2002). Transnational Networks and Skilled Labour Migration: Paper presented at The Ladenburger Diskurs "Migration" Gottlieb Daimler- Und Karl Benz-Stiftung, Ladenburg.

Vinogradov, E., \& Elam, E. (2010). A process model of venture creation by immigrant entrepreneurs, in the life cycle of new ventures. In C.G. Brush, L. Ø. Sørheim, L. Widding, \& L. Kolvereid (Eds.), Emergence, newness and growth. Northampton: Edward Elgar.

Vogt, W.P., Vogt, E.R., Gardner, D.C., \& Haeffele, L. (2014). Selecting the right analyses for your data: Quantitative, qualitative, and mixed methods. New York: Guilford Press.

Von Broembsen, M., \& Wood, E. (2005). Who provides South Africa's jobs? In M. Von Broembsen \& M. Wood (Eds.), General Entrepreneurship Monitor. South African Report (pp. 23-30). Cape Town: UCT Graduate School of Business.

Waldinger, R., Aldrich, H., \& Ward, R. (1990). Ethnic entrepreneurs. London: Sage.

Waldinger, R. (2002). Immigrant enterprise: A critique and reformation. Theory and society. Newbury Park: Sage.

Washinyira, T. (2015). How immigrants contribute to the SA economy. Groundup news article. Retrieved from www.groundup.org.za/article/how-immigrants-contribute-sa-economy_3043 on June 23, 2016.

Yetim, N. (2008). Social capital in female entrepreneurship. International Sociology, 23, 864-885.

Zikmund, W.G., Babin, B.J., Carr, J.C., \& Griffin, M. (2010). Business research methods (8th ed.). Mason, HO: Cengage Learning. 


\section{Authors}

The contribution of co-authors is equal and can be expressed as 33,33\% per each of the authors: B. L. Ngota prepared the introduction, literature review, and the material and methods section, including the references for the study, based on his MCOM dissertation, while E. E. Mang'unyi prepared statistical elaboration and drew conclusions. S. Rajkaran proofread and supervised the paper for publication.

\section{Bernard Lama Ngota}

Lecturer at the Walter Sisulu University, South Africa at the Department of Business management. He has a Bachelor of Commerce in Management (University of South Africa); Bachelor of Commerce Honours in Business Management (Walter Sisulu University); Master of Commerce in Business Management (Walter Sisulu University); PhD student in Commerce (Business Management; Nelson Mandela University). His research interests include entrepreneur-ship and small business management, marketing and innovative development in marketing and technology. He has already published as author or co-author of several articles in renowned journals (for instance SAJBM, IJAEE, IRMM).

Correspondence to: Bernard L. Ngota, PhD candidate, Walter Sisulu University, Private Bag X1, Mthatha 5117, South Africa, e-mail: bngota@wsu.ac.za ; bencolam@gmail

ORCID (1) http://orcid.org/0000-0002-0767-4118

\section{Sookdhev Rajkaran}

Associate Professor, Senior Lecturer and former Dean at the Faculty of Commerce and Administration, Walter Sisulu University. He was responsible for the development and execution of marketing programmes at the Walter Sisulu University. In his research, he specialises in marketing development, technological impact on management and marketing management, and quality management in higher education. His scientific articles can be found, among others, in South Africa Journal of Business Management, IRMM, Journal of Social Sciences, and many more.

Correspondence to: Prof. Sookdhev Rajkaran, PhD, Walter Sisulu University, Private Bag X1, Mthatha 5117, South Africa, e-mail:srajkaran@wsu.ac.za

ORCID (1) http://orcid.org/0000-0003-3337-5733

\section{Eric Ernest Mang'unyi}

Lecturer at the Catholic University of Eastern Africa-Kenya at the Department of Marketing and Management, School of Business. His research interests are in understanding different management practices including service quality management, services marketing, and corporate governance, along with their impacts on institutional prosperity. Moreover, he extends his research to examine the models that can lead to enhancing the aforementioned for the benefit of the organizations and society. He has published in these areas. He was recently a postdoctoral research fellow at Walter Sisulu University. He holds a DPhil in management studies from the University of KwaZulu-Natal (Pietermaritzburg Campus), South Africa.

Correspondence to: Eric Ernest Mang'unyi, PhD, The Catholic University of Eastern Africa, P.O. Box 62157-00200, Nairobi, Kenya, e-mail: ericm@cuea.edu

ORCID (1) http://orcid.org/0000-0002-5035-104X 


\section{Acknowledgements and Financial Disclosure}

The article came into being within the research project entitled "Economic Opportunities Created By Small Businesses Owned by African Immigrant Entrepreneurs in the Eastern Cape" financed by the NRF Scholarship grant conducted by Bernard Lama Ngota in 2016-2017.

The primary author will like to express his sincere gratitude to the Walter Sisulu University top management, especially Prof. R. Midgley, Vice-Chancellor of the University, for his candid support to the postgraduate students of the institution. Moreover, to $\operatorname{Dr}$ B.N. Cishe for heading the Research Development team in assisting postgraduate students with research funds approvals. Lastly, to NRF for providing research grants.

\section{Copyright and License}

This article is published under the terms of the Creative Commons

Attribution - NoDerivs (CC BY-ND 4.0) License

http://creativecommons.org/licenses/by-nd/4.0/

Published by the Centre for Strategic and International Entrepreneurship - Krakow, Poland 
